\title{
Inhibitory Effect of Caffeine on the In Vitro Uptake of Glucose by Rat Epididymal Adipose Tissue
}

\author{
John Anderson, Guy Hollifield and John A. Owen, Jr. \\ Department of Internal Medicine, University of Virginia School of Medicine Charlottesville, Virginia
}

Received July 2, 1966

Summary. Using an experimental design in which the segments of adipose tissue were randomly distributed, the effect of caffeine on the uptake of glucose from a Krebs bicarbonate medium by isolated rat epididymal adipose tissue has been studied. It was found that caffeine significantly inhibited the uptake of glucose in this system. This observation is consistent with previous observations on the metabolism of glucose-1 ${ }^{14} \mathrm{C}$, but does not differentiate between a primary effect on glueose uptake and an effect secondary to an inhibition of intermediary metabolism at some site within the cell.

Effet inhibiteur de la caféine sur la captation "in vitro" du glucose par le tissu adipeux épididymaire du rat.

Résumé. On a étudié l'effet de la caféine sur la cap. tation du glucose par le tissu adipeux épididymaire du rat placé dans du liquide de Krebs bicarbonaté. On a utilisé pour cela un plan expérimental dans lequel les segments de tissu adipeux étaient distribués au hasard. On a trouvé que la caféine inhibait significativement la captation du glucose dans ce système. Cette observation est en accord avec les observations antérieures sur le métabolisme du glucose-1-C $\mathbf{C}^{\mathbf{1 4}}$, mais ne permet pas de différencier un effet primaire sur la captation du glucose d'un effet secondaire à une inhibition du métabolisme intermédiaire en quelque site intracellulaire.

Hemmung der Glucose-Aufnahme des Ratten-Nebenhoden-Fettgewebes in vitro durch Coffein.

Zusammenfassung. Die Wirkung von Coffein auf die Glucoseaufnahme aus Krebs-Bicarbonat Puffer durch isoliertes Ratten-Nebenhoden-Fettgewebe wurde unter Anwendung eines gezielten Verteilungsschemas für die Fettgewebs-Segmente untersucht. Dabei ergab sich in diesem System eine signifikante Hemmung der Glucose-Aufnahme durch Coffein. Dieser Befund stimmt mit früheren Feststellungen über den Stoffwechsel von ${ }^{14} \mathrm{C}$-1-Glucose überein; es läßt sich jedoch nicht entscheiden, ob er durch eine primäre Wirkung auf die Glucose-Aufnahme bedingt ist oder ob ex einen Sekundäreffekt nach Hemmung des Intermediärstoffwechsel an unbekannter Stelle innerhalb der Zelle darstellt.

Key-words: caffeine, glucose uptake, incubated adipose tissue, epididymal adipose tissue.
We have previously reported the main effects and interactions of caffeine and insulin on the metabolism of ${ }^{14} \mathrm{C}$ labelled glucose by the isolated rat epididymal fat pad, finding that caffeine, $0.1 \mathrm{mg}(0.5 \mu \mathrm{mol})$ per $\mathrm{ml}$, inhibited the basal and insulin-stimulated ${ }^{14} \mathrm{CO}_{2}$ production and ${ }^{14} \mathrm{C}$ lipid incorporation from glucose-1-1 ${ }^{14} \mathrm{C}$ in Krebs bicarbonate buffer [1]. These results are compatible with diminished uptake of glucose by the fat pad, with impairment in the intracellular metabolism of glucose, or with both mechanisms operating simultaneously. The present studies were designed to demonstrate the specific effect of caffeine on glucose uptake by the isolated rat epididymal fat pad.

\section{Materials and Methods}

Six male Wistar rats (mean weight $230 \mathrm{gm}$ ) were housed in individual cages and allowed Purina Laboratory Chow and water ad libitum. Animals were killed by a blow to the head and the epididymal fat pads on each side were removed. From each pad, distal (D), medial (M), and proximal (P) segments (100$200 \mathrm{mg}$ ) were removed, weighed, and placed in $25 \mathrm{ml}$ incubation flasks containing $7 \mathrm{ml}$ of Krebs bicarbonate buffer at pH 7.4, with glucose $2.5 \mathrm{mg} / \mathrm{ml}(250 \mathrm{mg} / 100$ $\mathrm{ml}$ ). The 36 flasks were arranged in a completely random segment design. To 18 flasks was added $0.1 \mathrm{mg} / \mathrm{ml}$ of caffeine $^{1}$, the other 18 serving as controls. Immediately prior to incubation, $2 \mathrm{ml}$ of buffer was removed from each flask for estimation of glucose; the volume used for incubation was thus exactly $5 \mathrm{ml}$. The flasks were incubated with gentle agitation at $37^{\circ}$ for three hours in a Dubnoff incubator. The Nelson-Somogyi method [4] was used to measure glucose content of the buffer removed from the flasks before and after incubation. To provide a series of blanks, two further sets of 12 flasks were incubated without adipose tissue, one set containing buffer, glucose, and caffeine, the other, buffer and glucose alone. Pre- and post-incubation glucose estimations were also performed on these flasks.

\section{Results}

In the incubation blank flasks without adipose tissue, there was a consistent increase in the concentration of glucose after incubation, a veraging $+8.12 \mathrm{mg}$ per $100 \mathrm{ml}$ in those containing caffeine, and $+9.02 \mathrm{mg}$ per $100 \mathrm{ml}$ in those without. Thus the average increase over the three-hour incubation period for the 24 flasks was $+8.57 \mathrm{mg}$ per $100 \mathrm{ml}$, presumably reflecting a loss of $0.16 \mathrm{ml}$ water during incubation, despite all precautions. We, therefore, calculated the amount of glucose present in all the post-incubation flasks which con-

I Caffeine Hydrate - Mann Research Laboratories. 
tained adipose tissue, as based on the glucose concentration measured and an assumed volume of $4.84 \mathrm{ml}$ of buffer rather than $5 \mathrm{ml}$. On this basis the differences between the pre- and post-incubation levels were expressed as uptake of glucose in $\mu$ mols per gram of fat per three hours.

These figures are shown in ascending rank, together with the segments involved, in Table 1 . The average uptake of glucose was $13.36 \mu \mathrm{mol} / \mathrm{g}$ fat $/ 3$ hours in the control flasks, and $5.47 \mu \mathrm{mol} / \mathrm{g}$ fat $/ 3$ hours in the flasks with caffeine - an average effect of caffeine of $-7.89 \mu \mathrm{mol} / \mathrm{g}$ fat $/ 3$ hours. Scores were assigned to

Table 1. Uptake of Glucose - $\mu \mathrm{mol} / \mathrm{g}$ fat $/ 3 \mathrm{hrs}$

\begin{tabular}{|c|c|c|c|c|c|}
\hline \multicolumn{3}{|l|}{ Caffeine } & \multicolumn{3}{|l|}{ Control } \\
\hline Segment & Uptake & Rank & Segment & Uptake & Rank \\
\hline $\mathrm{RP}$ & 24.661 & 35 & RM & 24.830 & 36 \\
\hline LP & 21.357 & 31 & RP & 23.202 & 34 \\
\hline $\mathrm{LM}$ & 17.039 & 27 & LM & 23.065 & 33 \\
\hline $\mathrm{RM}$ & 16.340 & 26 & PR & 21.820 & 32 \\
\hline LP & 15.864 & 24 & $\mathrm{LP}$ & 18.722 & 30 \\
\hline $\mathrm{LM}$ & 9.328 & 18 & LP & 17.163 & 29 \\
\hline $\mathrm{RD}$ & 4.938 & 16 & $\mathrm{RM}$ & 17.091 & 28 \\
\hline RD & 4.635 & 15 & $\mathrm{LD}$ & 16.045 & 25 \\
\hline $\mathrm{LD}$ & 4.227 & 14 & $\mathrm{LD}$ & 14.587 & 23 \\
\hline $\mathrm{LD}$ & 3.085 & 12 & $\mathbf{R M}$ & 14.539 & 22 \\
\hline $\mathrm{RP}$ & 2.578 & 11 & LM & 13.265 & 21 \\
\hline $\mathrm{LD}$ & 2.518 & 10 & RD & 12.939 & 20 \\
\hline LP & 0.000 & 7 & LP & 11.632 & 19 \\
\hline RP & -1.211 & 6 & $\mathrm{LM}$ & 9.028 & 17 \\
\hline $\mathrm{RM}$ & -2.172 & 5 & LD & 3.839 & 13 \\
\hline LM & -5.203 & 3 & RD & 1.452 & 9 \\
\hline RM & -6.171 & 2 & $\mathrm{RP}$ & 0.760 & 8 \\
\hline $\mathrm{RD}$ & -13.408 & 1 & $\mathrm{RD}$ & 3.497 & 4 \\
\hline \multicolumn{3}{|c|}{ Average $\quad 5.47$} & \multicolumn{3}{|c|}{13.36} \\
\hline $\begin{array}{l}\text { Rank } \\
\text { Sum. }\end{array}$ & & 263 & \multicolumn{2}{|l|}{$\begin{array}{l}\text { Rank } \\
\text { Sum. }\end{array}$} & 403 \\
\hline
\end{tabular}

the individual figures according to rank, and the significance of the difference between treatments estimated using Wilcoxon's rank sums test $[3](\mathbf{P}<.05$ two sided). The more familiar t-test was not used because we were reluctant to make the necessary assumption of a normal distribution in the population; the samples themselves were rather small and showed some trouble. some deviation from normal. Therefore we preferred the Wilcoxon test, which does not depend on these assumptions, is much easier to calculate, and whose power-efficiency is $95.5 \%$.

\section{Discussion}

The finding that caffeine significantly reduces the uptake of glucose by the isolated rat epididymal fat pad is not unexpected in view of the observations previously reported [1]. It also confirms the observations of Vaughan on the effects of caffeine on glucose uptake by adipose tissue [5]. Nevertheless, such data do not differentiate conclusively between a primary effect of caffeine on glucose uptake and a secondary effect which might be dependent upon a primary intra-cellular inhibitory action. Such an action would, by inhibiting the metabolism of glucose within the cell, be expected to produce a secondary inhibition of glucose uptake across the cell membrane. Further studies in progress using different substrates do in fact show an undoubted intracellular site of action, and strongly suggest a primary inhibition of lipid biosynthesis [2].

Acknowledgement. This work was supported by the U. S. Public Health Services, grants No. 5 RO1 AMOO 893-12 (Dr. Hollifieto) and 2 TI HE 5544-06 (Dr. OWEN).

\section{Bibliography}

[1] Anderson, J., G. Hollifield and J.A. Owen, Jr.: The effects of caffeine, deoxyribose nucleic acid and insulin on the metabolism of glucose by adipose tissue in vitro. Metabolism 15, 30-38 (1966).

[2] - - - Inhibition by caffeine of lipogenesis from acetate in the epididymal fat pad of the rat. (In preparation).

[3] Mainland, D. : Elementary medical statistics. Second Edit. Philadelphia, W.B. Saunders Co., p. 284 (1964).

[4] Somogyt, M.: Determination of blood sugar. J. biol. Chem. 160, 69-73 (1945).

[5] VAUGHA.N, M. : Effect of hormones on glucose metabolism in adipose tissue. J. biol. Chem. 326, $3125-3130$ (1961).

John Anderson, M.B., M.R.C.P.

Department of Medicine

Royal Victoria Infirmary

Newcastle-upon-Tyne 1

England 